Part of Journal of Research of the National Bureau of Standards, Volume 19, November 1937

\title{
EVALUATION OF CRUSH-RESISTANT FINISHING TREATMENTS FOR FABRICS
}

\author{
By Herbert F. Schiefer
}

\section{ABSTRACT}

The results of measurements by the compressometer method of certam compressional characteristics of representative transparent velvet fabrics before and after the application of commercial crush-resistant finishes are reported and discussed. These finishing treatments markedly change the compression and recovery characteristics of the untreated fabries and, in general, increase the "compressional resilience" of the pile. These changes appear to correlate with the changes in the appearance produced in the fabries when small areas of the various specimens are compressed with the compressometer.

\section{CONTENTS}

I. Introduction

II. Procedure

III. Discussion of results

\section{INTRODUCTION}

The utility of pile fabrics depends, among other things, upon the resistance to crushing or deformation and matting of the yarns and fibers forming the pile. Pile dress fabrics, notably transparent velvets with rayon pile, have been particularly troublesome in this respect. The application to such fabrics of synthetic resins by what are called crush-resistant finishing treatments has resulted in much more serviceable products. The work reported in this paper was undertaken to determine the applicability of the compressometer to the evaluation of crush-resistant treatments on pile dress fabrics.

\section{PROCEDURE}

Representative transparent velvet fabrics, before and after the application of crush-resistant finishing treatments, were furnished for the work by several manufacturers. Samples of these fabrics were conditioned by exposure for several days in an atmosphere of 65-percent relative humidity and a temperature of $70^{\circ} \mathrm{F}$, and were tested in this condition.

The compressometer illustrated in figure 1 is described in detail in a previous publication. ${ }^{1}$ By turning the knurled knobs, shown in the center of the figure, the circular presser foot, which is 1 inch in

\footnotetext{
${ }^{1}$ Herbert F. Schiefer. The compressometer, an instrument for evaluating the thickness, compressibility, and compressional resilience of textlles and similar materials. BS J. Research 10, 705 (1933) RP561.
}

$19521-37-6$ 
diameter, is lowered and a fabric placed on the anvil below it is compressed. The load applied to the fabric by the foot for any position of the knurled knobs is indicated on the upper dial of the instrument. The thickness of the fabric at that load, that is, the distance from the presser foot to the anvil, is indicated on the lower dial.

The fabric to be tested was subjected to a series of increasing pressures from 0.25 to $5.0 \mathrm{lb} / \mathrm{in} .{ }^{2}$ in increments of $0.25 \mathrm{lb} / \mathrm{in} .{ }^{2}$ for pressures up to $1.0 \mathrm{lb} / \mathrm{in} .{ }^{2}$ and of $0.5 \mathrm{lb} /$ in. $^{2}$ thereafter, and the thickness at each pressure was observed and recorded. Similar observations were then made for decreasing pressures. The time between observations was about 10 seconds. Each fabric was measured in at least five different places and the averages of the values for each pressure were used. It was found necessary to adjust the presser foot parallel to the anvil before starting to measure each new place on pile fabrics.

The results were plotted in the form of curves, showing the compression and recovery of the fabrics. In addition, the energy expended in compressing the fabric as the pressure was increased from 0.25 to $5.0 \mathrm{lb} / \mathrm{in}^{2}{ }^{2}$ and the energy recovered when the pressure was decreased over this range were calculated. ${ }^{2}$ The ratio of the energy of recovery to the energy of compression was taken as a measure of the "compressional resilience" of the fabircs.

\section{DISCUSSION OF RESULTS}

In a transparent velvet the cut tufts of the pile yarns, which are exposed on one side of the fabric, are bound in with the warp and filling yarns comprising the woven back. The pile yarns are composed of numerous rayon fibers which project a given distance beyond the surface of the back fabric and are oriented substantially perpendicular to it. The load exerted by the compressometer is applied to the ends of the pile fibers, substantially parallel to their longitudinal axes, and tends to bend them over. The amount of bending of the fibers of a given fabric depends upon the number of fibers per unit area, their stiffness, and the applied load. The fibers deflect in all directions, and thereby reinforce each other to some degree. However, as the load is increased a value is eventually reached which is greater than can be supported by the pile fibers and a sudden bending over of the fibers at their base results. This collapse of the pile, equivalent to a sudden decrease in the thickness of the fabric, is indicated by an abrupt change in the compression curve. A fabric in which this condition has been produced is here described as having been "crushed."

Typical curves representing the compression and recovery of two transparent velvet fabrics, measured before and after the application of crush-resistant treatments, are plotted in figure 2. They show clearly that the pile of both fabrics before treatment is crushed by pressures less than $5 \mathrm{lb} / \mathrm{in}^{2}{ }^{2}$ and that the fabrics do not recover to their original thickness when the load is removed. The treatment applied to fabric $A$, no. 4 in table 1 , has greatly improved it both with respect to the extent of the compression, which is very small for a

${ }_{2}^{2}$ The energy of compression is equal to the area between the compression curve and the thickness axis, that is, the vertical axis. The energy of recovery is the corresponding area for the recovery curve Unless a planimeter is available, the simplest method of calculating these areas is to divide each area by horizontal lines into a series of trapezoids.; The area of each trapezoid is calculated by using the formula "area equals base times average altitude", where the base is the distance between the two horizontal lines forming the trapezoid and the average altitude is the average of these two horizontal lines, that is, distance from the thickness axis to their intersection with the curve. 


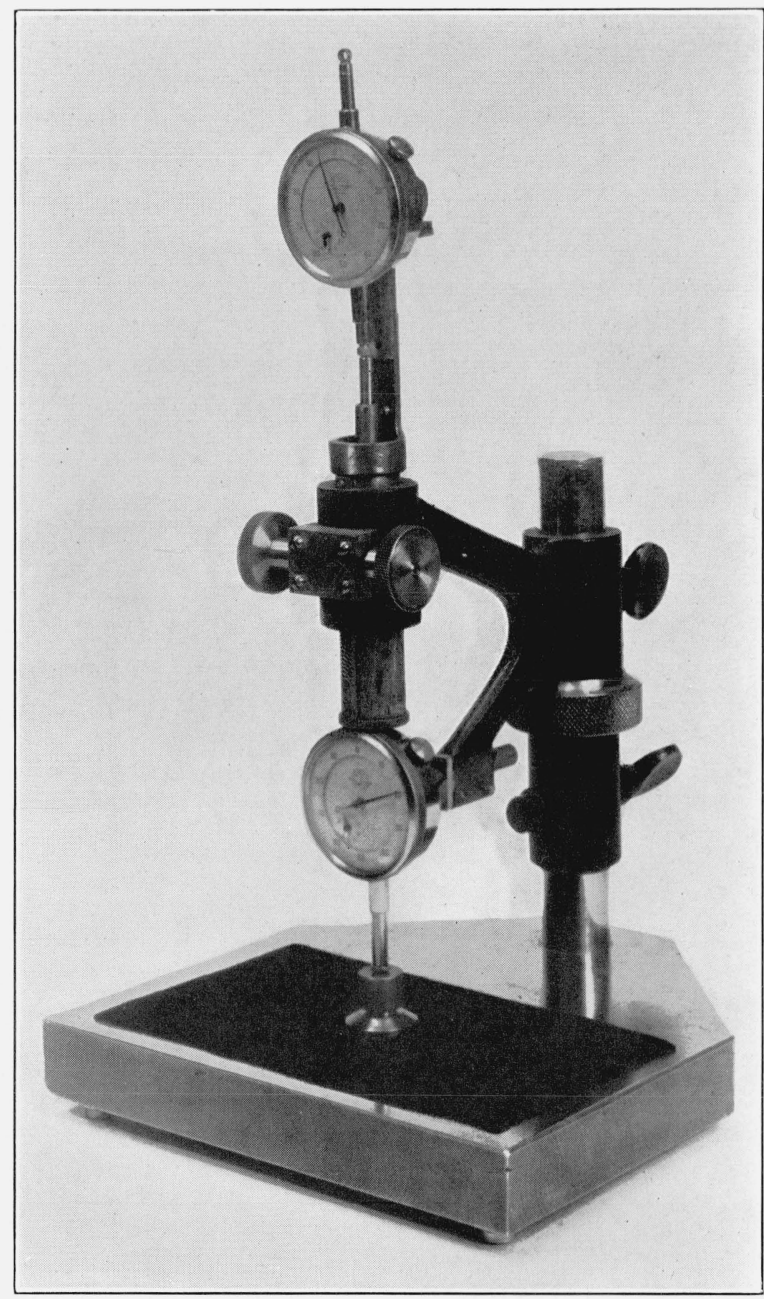

Figure 1.-Compressometer. 
pressure of $5 \mathrm{lb} / \mathrm{in}^{2}$ and with respect to the recovery. The pile of this fabric is not crushed. The improvement in fabric $B$, no. 5 in table 1 , resulting from the treatment is much less with respect to the compression and recovery and the pile of the treated fabric is crushed.

Two of the six velvet fabries tested were compressed but little under a pressure of $5 \mathrm{lb} / \mathrm{in}^{2}{ }^{2}$, either before or after the application of the crush-resistant treatment. The compression and recovery curves of these fabrics are similar to the treated curves of velvet $A$, figure 2 . In two cases the pile was crushed before but not after the treatment (fig. 2, velvet $A$ ), while for the remaining two fabrics the pile was crushed both before and after the treatment (fig. 2, velvet $B$ ). The compression and recovery curves obtainable with the compressometer
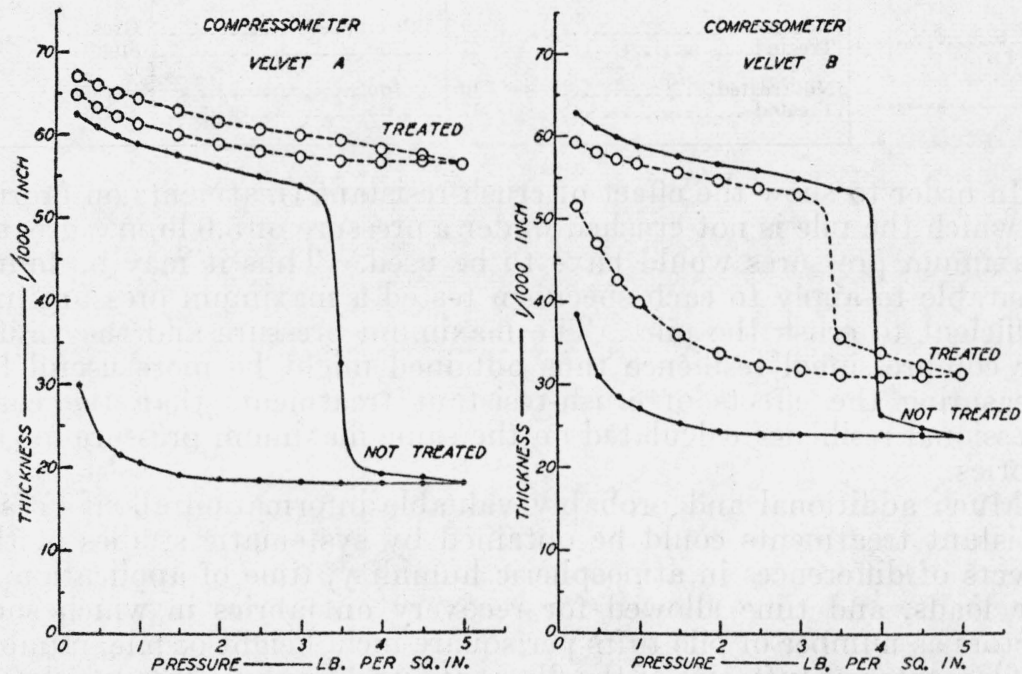

FIGURE 2.-Effect of crush-resistant finishing treatments on compression and recovery curves of two transparent velvet fabrics as measured by the compressometer.

show clearly the difference in these fabrics. It is concluded that the instrument should be useful in evaluating the effectiveness of crushresistant treatments and in studying variations in them.

In general there was observed a more marked change in appearance between the compressed and uncompressed areas of an untreated velvet fabric than in the treated specimen of the same fabric. This difference in appearance was more permanent in the untreated fabrics. Also, in comparing the six velvet fabrics with each other with respect to appearance, the two untreated velvets in which the pile was not crushed changed less in appearance than the four untreated velvets in which the pile was crushed. Similarly, the four treated velvets in which the pile was not crushed changed less in appearance than the two treated velvets in which the pile was crushed.

The compressional resilience for each of the six velvet fabrics tested is given in table 1. This quantity is increased by the crush-resistant finishing treatments. It can be correlated with the change in appearance produced when the compressed areas are compared with areas that have not been compressed. These changes in appearance are also noted in the table. 
TABLE 1.-Effect of crush-resistant finishing treatments on transparent-velvet fabrics

\begin{tabular}{|c|c|c|c|c|}
\hline Specimen & Designation & $\begin{array}{l}\text { Compres- } \\
\text { sional re- } \\
\text { silience }\end{array}$ & Remarks & $\begin{array}{l}\text { Change in ap- } \\
\text { pearance }\end{array}$ \\
\hline & $\left\{\begin{array}{l}\text { Not treated } \\
\text { Treated }\end{array}\right.$ & $\begin{array}{r}\text { Percent } \\
38 \\
50\end{array}$ & $\begin{array}{l}\text { Pile not crushed } \\
\text { do }\end{array}$ & $\begin{array}{l}\text { Slight. } \\
\text { Very slight. }\end{array}$ \\
\hline 2 & $\left\{\begin{array}{l}\text { Not treated.... } \\
\text { Treated......... }\end{array}\right.$ & $\begin{array}{l}41 \\
43\end{array}$ & do do & $\begin{array}{l}\text { Do. } \\
\text { Do. }\end{array}$ \\
\hline $3 . .$. & $\left\{\begin{array}{l}\text { Not treated.... } \\
\text { Treated...... }\end{array}\right.$ & $\begin{array}{r}6 \\
46\end{array}$ & $\begin{array}{l}\text { Pile crushed } \\
\text { Pile not crushed............ }\end{array}$ & $\begin{array}{l}\text { Great. } \\
\text { Very slight. }\end{array}$ \\
\hline 4 & $\left\{\begin{array}{l}\text { Not treated...- } \\
\text { Treated...... }\end{array}\right.$ & $\begin{array}{r}7 \\
55\end{array}$ & $\begin{array}{l}\text { Pile crushed } \\
\text { Pile not crushed. }\end{array}$ & $\begin{array}{l}\text { Very great. } \\
\text { Very slight. }\end{array}$ \\
\hline $5 \ldots$ & $\left\{\begin{array}{l}\text { Not treated } \\
\text { Treated }\end{array}\right.$ & $\begin{array}{r}9 \\
27\end{array}$ & Pile crushed......... & $\begin{array}{l}\text { Great. } \\
\text { Slight. }\end{array}$ \\
\hline $6 \ldots$ & $\left\{\begin{array}{l}\text { Not treated } \\
\text { Treated }\end{array}\right.$ & $\begin{array}{l}10 \\
17\end{array}$ & do do & $\begin{array}{l}\text { Great. } \\
\text { Slight. }\end{array}$ \\
\hline
\end{tabular}

In order to show the effect of crush-resistant treatments on fabrics in which the pile is not crushed under a pressure of $5.0 \mathrm{lb} / \mathrm{in}^{2}{ }^{2}$, greater maximum pressures would have to be used. Thus it may be found desirable to apply to each specimen tested a maximum pressure just sufficient to crush the pile. The maximum pressure and the values for compressional resilience thus obtained might be more useful for measuring the effects of crush-resistant treatments than the compressional resilience calculated on the same maximum pressure for all fabrics.

Much additional and probably valuable information about crushresistant treatments could be obtained by systematic studies of the effects of differences in atmospheric humidity, time of application of the loads, and time allowed for recovery on fabrics in which such factors as number of pile tufts per square inch, hejght of pile, number of filaments per tuft, size of the filaments, and finishing treatments are varied systematically. The present work indicates that the compressometer would be useful for such an investigation and the results should be valuable to both manufacturers and users of pile fabrics.

The author acknowledges his indebtedness to Kenneth Barnard of the Pacific Mills and chairman of the Committee on Test Methods for Crease Resistance and Permanent Finishes of the American Association of Textile Chemists and Colorists, and to Dr. D. H. Powers, who is also a member of the committee, for suggestions and interest in this work. Grateful acknowledgment is also made to Röhm and Haas Co., Cheney Brothers, and the Rossie Velvet Co. for furnishing material for testing.

Washington, September 3, 1937. 